\title{
Pengaruh Tingkat Pendidikan, Love of Money dan Moral Reasoning Pada Persepsi Etis Mahasiswa Akuntansi
}

\author{
Ni Kadek Sri Puspita Dharmayanti ${ }^{1}$ \\ Fakultas Ekonomi dan Bisnis \\ Universitas Udayana, Indonesia. \\ Email: sripuspita96@gmail.com
}

\author{
Ni Putu Sri Harta Mimba ${ }^{2}$ \\ Fakultas Ekonomi dan Bisnis \\ Universitas Udayana, Indonesia.
}

\begin{abstract}
ABSTRAK
Penelitian ini mengambil sampel yaitu seluruh mahasiswa aktif program diploma angkatan 2016, S1 akuntansi angkatan 2015, PPAK angkatan 2018, dan S2 akuntansi angkatan 2017 Fakultas Ekonomi dan Bisnis Universitas Udayana dengan menggunakan metode probability sampling dengan teknik random. Berdasarkan hasil perhitungan dengan rumus Slovin didapat sampel sejumlah 167 orang. Pengumpulan data dalam penelitian ini menggunakan teknik kuesioner secara online. Hasil penelitian menunjukan mahasiswa akuntansi dengan tingkat pendidikan yang tinggi akan memiliki persepsi yang tinggi pula. Mahasiswa akuntansi dengan tingkat love of money yang tinggi akan memiliki persepsi etis yang rendah. Mahasiswa akuntansi dengan tingkat moral reasoning yang tinggi akan memiliki persepsi etis yang tinggi. Persepsi etis akan berpengaruh pada perilaku etis dari mahasiswa akuntansi. Hal tersebut berarti, bahwa tingkat pendidikan yang tinggi dan tingkat moral reasoning yang tinggi akan meningkatkan persepsi etis yang dimiliki mahasiswa akuntansi, sedangkan tingginya tingkat love of money akan mempengaruhi rendahnya persepsi etis mahasiswa
\end{abstract}

Kata Kunci : $\quad$ Akuntansi; Love Of Money; Mahasiswa; Persepsi; Moral Reasoning.

Effects of Educational Level, Love of Money and Moral
Reasoning on Ethical Perceptions of Accounting Students

\begin{abstract}
This study took the sample of all active students in the 2016 diploma program, undergraduate accounting undergraduate 2015, PPAK batch 2018, and postgraduate accounting for 2017 Faculty of Economics and Business, Udayana University using probability sampling method with random techniques. Based on the results of calculations with the Slovin formula obtained a sample of 167 people. Data collection in this study using online questionnaire techniques. The results showed that accounting students with a high level of education would also have high perceptions. Accounting students with a high level of love of money will have a low ethical perception. Accounting students with high levels of moral reasoning will have high ethical perceptions. Ethical perception will influence the ethical behavior of accounting students. This means that a high level of education and a high level of moral reasoning will enhance the ethical perceptions of accounting students, while the high level of love of money will affect the low ethical perceptions of students.
\end{abstract}

Keywords: Accounting; Love Of Money; Students; Perception; Moral Reasoning.

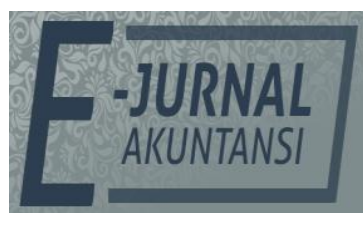

E-JA

e-Jurnal Akuntansi e-ISSN 2302-8556

Vol.298 No. 1

Denpasar, Oktober

2019

Hal. 242-257

Artikel masuk:

12 Agustus 2019

Tanggal diterima: 27 September 2019 


\section{PENDAHULUAN}

Etika merupakan cara pandang bagaimana menilai sesuatu apakah benar atau salah. Etika akan mampu menekan timbulnya perselisihan antar masyarakat pada suatu permasalahan, karena etika dapat menjadi pedoman dan acuan dalam kehidupan. Etika hadir sebagai pedoman masyarakat dalam berperilaku serta menentukan apa yang benar dan salah sehingga mampu terciptanya keharmonisan hidup. Etika akan menjadi landasan bagi seseorang dalam menentukan persepsi etis yang dimilikinya.

Seseorang memilih, berusaha, dan menginterpretasikan rangsangan dalam gambar yang terpadu dan penuh arti (Lubis, 2011). Seseorang kerap melakukan segala sesuatu berdasarkan persepsinya masing-masing tanpa mementingkan kenyataan sebenarnya, dikarenakan persepsi bersifat subjektif dan kondisional. Persepsi seseorang dapat berubah dipengaruhi oleh situasi (kondisional).

Persepsi seseorang berbeda dikarenakan pengaruh faktor pemersepsi, faktor dalam situasi dan faktor pada target (Lubis, 2011). Sikap, kebutuhan, pengarapan dan pengalaman menjadi faktor dalam pemersepsi. Faktor dalam situasi terdiri dari waktu, keadaan dan situasi sosial. Faktor pada target diantaranya sesuatu hal yang baru, bunyi, gerakan, ukuran serta latar belakang. Persepsi akan menjadi sangat penting dalam kaitannya dengan pengambilan keputusan.

Persepsi seseorang mahasiswa mengenai suatu permasalahan harus diseragamkan dan berpedoman pada konsep etika. Perbedaan persepsi sering timbul dikarenakan kurangnya wawasan, pengalaman dan kondisi lingkungan yang berbeda dari masing-masing individu. Pendidikan keprilakuan menjadi salah satu solusi untuk menyatukan pemahaman dan persepsi mahasiswa. Persepsi seorang mahasiswa mengenai perbuatan baik dan buruk sangatlah penting karena akan mereka praktekkan di lingkungan kerja dan masyarakat dimasa mendatang.

Persepsi etis seseorang dipengaruhi oleh banyak faktor, seperti tingkat pendidikan, love of money dan moral reasoning seseorang. Ketiga faktor tersebut diduga memiliki dampak yang cukup besar dalam memengaruhi tingkat persepsi etis seorang mahasiswa. Hal ini dapat dilihat dari banyaknya kasus pelanggaran etika yang terkait dengan faktor tersebut, dimana hal ini menandakan rendahnya persepsi etis khususnya pada profesi akuntan. Mahasiswa akuntan akan memiliki persepsi beragam terkait kasus yang ada, sebagian menganggap pelanggaran etika sebagai hal yang biasa dan sisanya menganggap pelanggaran sebagai tindakan yang salah dan tak seharusnya dilakukan.

Kasus manipulasi laba, penggelapan pajak dan berbagai kesalahan pencatat dalam laporan keuangan yang disengaja untuk keuntungan pribadi atau kelompok tentunya tidak akan terjadi apabila seorang akuntan memiliki etika dalam bekerja. Seorang akuntan dengan pengetahuan yang tinggi namun nilai etika yang rendah hanya akan menggunakan kemampuannya untuk menguntungkan dirinya sendiri dan merugikan pihak lain.

Kasus yang melibatkan profesi akuntan diantaranya adalah kasus korupsi pembelian sebagian aset milik ROC Oil Company Ltd pada tahun 2009 oleh 
mantan Direktur Utama PT. Pertamina Karen Galaila Agustiawan. Kasus yang melibatkan mantan Direkrut Utama ini merugikan keuangan negara hingga Rp.568 miliar (Chairunnisa, 2018). Karen merupakan Guru Besar di Harvard University, Boston, Amerika Serikat sejak tahun 2014 dan dirinya masuk dalam daftar Asia's 50 Power Businesswomen majalah Forbes.

Kasus Karen menunjukkan bahwa tingkat pendidikan yang tinggi tidak menjamin seseorang memiliki etika profesi yang tinggi pula. Sebagai salah satu Guru Besar di Harvard University, Karen justru melakukan tindakan kecurangan yang mencoreng profesi akuntan. Hal ini menunjukkan adanya indikasi metode pendidikan di Indonesia yang masih belum optimal dan lemahnya pengajaran mengenai etika serta kejujuran yang seharusnya menjadi dasar sebelum pemberian pendidikan mengenai ilmu pengetahuan. Pendidikan etika dan karakter kurang menjadi perhatian bagi tenaga pendidik dan hanya memfokuskan pendidikan mengenai mata pelajaran tertentu. Faktor lain yang memengaruhi persepsi etis mahasiswa adalah love of money.

Kecintaan seseorang pada uang mampu memengaruhi perilaku etisnya. Seseorang yang sangat terobsesi dengan uang dapat melakukan kecurangan dan melanggar norma etika guna memenuhi ambisinya. Pada profesi akuntan hal ini tentunya akan sangat membahayakan dan merugikan banyak pihak. Kasus penggelapan pajak yang merugikan negara mencapai Rp. 7,9 Milliar dilakukan oleh tiga perusahaan yakni PT. Jasa Sumatera Travelindo (JST), PT. Batanghari Oilindo Palm (BIP), dan PT. Putri Windu Semesta (PWS) ke kantor pelayanan pajak (KPP) Kota Medan dari tahun 2007-2008, namun setelah dilakukan audit pada tahun 2017 ditemukan penyimpangan pajak yang merugikan negara (Hidayat, 2017).

Berbagai kasus yang terjadi secara tidak langsung memengaruhi kondisi mental akuntan, termasuk mahasiswa tingkat akhir yang akan memasuki dunia kerja. Mahasiswa akuntansi yang merupakan calon akuntan profesional dimasa mendatang, seharusnya sejak dini diberikan pemahaman lebih mengenai etika, bagaimana seharusnya menggunakan ilmu yang didapatkan di kampus untuk tujuan kebaikan. Fenomena yang terjadi saat ini masih minimnya mata kuliah mengenai etika di kampus, dan jika ada masih belum optimal sehingga dianggap bukan mata kuliah penting dibandingkan dengan yang lainnya. Permasalahan etika mahasiswa dalam bekerja dapat dijelaskan dengan teori motivasi yang menjelaskan hal-hal yang mendoroang seseorang berprilaku etis.

Teori motivasi digunakan menjelaskan hubungan antar variabel. Teori motivasi menjelaskan bahwa terdapat dorongan dalam diri seseorang untuk melakukan sesuatu dan tetap tertarik untuk menyelesaikannya (Frederickson, Miller and Cline, 2008) Teori motivasi menjelaskan bahwa dalam menjalani hidup, seseorang memerlukan kebutuhan fisiologis yakni berupa makanan, tempat tinggal dan pendapatan yang layak (Hasibuan, 2011). Faktor yang memengaruhi perilaku seseorang salah satunya adalah tingkat pendidikan yang dimiliki.

Seseorang akan menempuh pendidikan guna mendapatkan pekerjaan dan memenuhi kebutuhannya. Hal ini sejalan dengan teori motivasi, yakni kebutuhan manusia akan makanan karena tanpa adanya pendidikan tentunya akan sulit mendapatkan pekerjaan dan tidak mampu memenuhi kebutuhan 
hidup. Seseorang ketika menempuh pendidikan akan mendapatkan nilai etika dan memengaruhi persepsi etisnya. Tingkat pendidikan akan memengaruhi perilaku etis seseorang dalam kaitannya dengan keinginan pemenuhan kebutuhan hidup.

Seseorang dengan tingkat pendidikan tinggi akan mampu menganalisa dan menyelesaikan permasalahan yang kompleks sehingga mampu meningkatkan peningkatan pandangan akan moral dan etika (Kohlberg, 1981). Seseorang yang memiliki pendidikan tinggi umumnya akan berperilaku etis (Dellaportas, 2006). Pendidikan memberikan mereka gambaran akan ganjaran apa yang akan terjadi apabila mereka melanggar aturan yang ada dan membuat mereka akan berperilaku etis serta memikirkan dampak jangka panjang dari setiap keputusan yang diambil. Orang dengan pendidikan tinggi akan lebih berhati-hati dalam melakukan sesuatu hal. Faktor lain seperti love of money akan memengaruhi pemikiran seorang mengenai tindakan etis.

Seseorang dengan kecintaan pada uang yang tinggi cenderung menginginkan kekuasaan dan pendapatan yang tinggi, hal ini sejalan dengan teori motivasi kepuasan Maslow terkait tingkat kebutuhan dasar manusia yakni kebutuhan fisiologis. Kebutuhan fisiologis berupa makanan, minuman, serta pendapatan yang layak. Kebutuhan fisiologis inilah yang mendorong seseorang untuk berperilaku etis guna memenuhi kebutuhannya.

Love of money mampu memengaruhi sikap profesionalitas seseorang (Sipayung and Cahyonowati, 2015). Pekerja dengan kecintaan uang yang tinggi umumnya tidak merasa puas dan nyaman dengan pekerjaannya, hal ini yang mendorong mereka berperilaku tidak etis (Tang and Chiu, 2003). Love of money membuat seseorang menjadi tamak dan mementingkan dirinya sendiri, mereka akan melakukan apapun demi memenuhi hasrat akan uang. Sesungguhnya love of money dapat dijadikan alat untuk mengendalikan kinerja seseorang. Jika perilaku tidak puas menyebabkan pekerja berperilaku tidak etis maka dengan adanya lingkungan kerja yang baik, bonus, promosi jabatan dan hal lainnya yang mampu meningkatkan kepuasan kerja. Seseorang dengan tingkat love of money yang tinggi justru mampu dikendalikan dengan penawaran bonus apabila kinerja mereka baik dan memiliki etika kerja. Faktor lain yang sangat mengkhusus pada pribadi seseorang adalah moral reasoning, yang akan menentukan tindakan etis mereka.

Karakteristik personal individu seperti moral reasoning akan memengaruhi keputusan yang diambil apakah sesuai etika atau melanggar etika yang ada. Seseorang umumnya mengalami perdebatan batin akan permasalahan etika, perdebatan ini bergantung seberapa jauh kemampuan seseorang dalam penalaran moral (Welton and Lagrone, 1994). Semakin tinggi penalaran moral akan memudahkan seseorang dalam mengambil keputusan dan cenderung berperilaku etis (Rest et al., 2000). Moral mampu menunjukkan sikap sebenarnya seseorang dalam menjalani kehidupan khususnya dalam lingkungan pendidikan dan pekerjaan. Moral dan etika umumnya dimiliki oleh mereka yang mempunyai kesadaran untuk berperilaku sesuai norma yang ada dan kemudian menjadi budaya untuk terus dilakukan. Kesadaran ini berbeda-beda pada setiap orang, karena setiap orang memiliki kepekaan yang berbeda pada norma dan 
nilai yang ada disekitarnya, sehingga moral reasoning dapat memicu perilaku etis seseorang.

Teori motivasi menjelaskan bahwa dalam menjalani hidup, seseorang memerlukan kebutuhan fisiologis yakni berupa makanan, tempat tinggal dan pendapatan yang layak (Hasibuan, 2011). Seseorang akan menempuh pendidikan guna mendapatkan pekerjaan dan memenuhi kebutuhannya. Jika ditelaah kedalam, tingkat pendidikan sendiri dianggap mempengaruhi persepsi etis mahasiswa akuntansi karena semakin tinggi tingkat pendidikan, pengetahuan yang dimiliki juga akan meningkat. Semakin banyak pengetahuan yang mereka ketahui maka akan membantu mereka untuk bisa memberikan persepsi maupun tanggapan terhadap krisis etis yang melibatkan profesi akuntan. Pengetahuan yang didapatkan selama menempuh pendidikan yang dimiliki oleh mahasiswa akuntansi akan mempengaruhi persepsi etis mereka. Kohlberg (1981) menyatakan bahwa orang-orang yang memiliki tingkat pendidikan lebih tinggi dapat memahami masalah yang lebih kompleks sehingga akan menyebabkan tingkat penalaran moral lebih baik.

Hasil penelitian Dellaportas (2006) menemukan bahwa pendidikan etika memiliki dampak yang positif dan signifikan terhadap etika mahasiswa akuntansi. Hal ini berarti bahwa mahasiswa dengan tingkat pendidikan yang tinggi akan cenderung berperilaku lebih etis dibandingkan mahasiswa dengan tingkat pendidikan yang lebih rendah (Elias and Farag, 2010). Lopez et al. (2005) juga menguji efek dari tingkat pendidikan dalam sekolah bisnis dan faktor individu lain, seperti kebudayaan intranasional, spesialisasi dalam pendidikan, dan jenis kelamin pada persepsi etis. Hasil penelitian menunjukkan menunjukkan bahwa tingkat pendidikan, kebudayaan intranasional, dan jenis kelamin berpengaruh secara signifikan terhadap persepsi etis. Selanjutnya, mereka menemukan bahwa perilaku etis cenderung tinggi pada tingkat pendidikan yang lebih tinggi. Berdasarkan uraian penjelasan di atas maka rumusan hipotesis sebagai berikut.

$\mathrm{H}_{1}$ : Tingkat pendidikan berpengaruh positif pada persepsi etis mahasiswa akuntansi.

Teori motivasi menyebutkan bahwa ada dorongan dari dalam diri seseorang yang menyebabkan seseorang mampu melakukan sesuatu kegiatan untuk mencapai tujuan. Love of money dipengaruhi oleh movitasi dalam diri masing-masing orang. Love of money sangat berkaitan dengan sifat tamak dan rakus. Seseorang dengan love of money yang tinggi cenderung memiliki kecintaan berlebihan pada uang dan akan menilai segala sesuatu hal dengan uang. Hasibuan (2011) menjelaskan bahwa manusia memiliki beberapa kebutuhan yang diklasifikasikan kedalam beberapa tingkatan, yakni: fisiologis, kebutuhan rasa aman, harga diri dan kebutuhan aktualisasi. Kebutuhan tersebut dapat terpenuhi dengan adanya uang, namun tingkat kecintaan seseorang pada uang yang berlebih dapat menimbulkan ketamakan.

Teori motivasi erat kaitannya dengan sifat tamak seseorang akan keinginannya terhadap uang. Uang membuat seseorang mampu memenuhi berbagai kebutuhan dasar dalam teori motivasi. Semakin tinggi hasrat seseorang memenuhi kebutuhannya dan kecintaannya pada uang, semakin tinggi pula 
kemungkinan orang tersebut berperilaku tidak etis. Desakan dalam memenuhi kebutuhan akan membuat seseorang berperilaku tidak etis.

Seseorang cenderung akan melakukan apapun demi mendapatkan uang, termasuk berperilaku tidak etis. Seseorang dengan love of money yang rendah cenderung memiliki kepuasan kerja yang rendah pula. Love of money dan persepsi memiliki hubungan yang negatif. Terdapat beberapa hasil penelitian yang mengukur pengaruh love of money pada perilaku etis seseorang.

Hasil penelitian Charismawati (2011) pada persepsi etis mahasiswa akuntansi menunjukkan hubungan negatif antara love of money dengan persepsi etis mahasiswa akuntansi. Semakin tinggi kecintaan seseorang pada uang, maka akan semakin tidak etis perilaku seseorang. Love of money memiliki hubungan negatif dengan perilaku etis (Aziz, 2015). Love of money berpengaruh negatif dan signifikan secara statistik terhadap Persepsi etis mahasiswa akuntansi. Semakin tinggi sifat love of money mahasiswa tersebut, maka akan semakin rendah persepsi etis yang dimiliki (Kurniawan, 2017). Berdasarkan uraian penjelasan diatas maka rumusan hipotesis sebagai berikut.

$\mathrm{H}_{2}$ : Love of money berpengaruh negatif pada persepsi etis mahasiswa akuntansi

Teori motivasi merupakan teori yang didasarkan pada kebutuhan insan dan kepuasannya. Moral reasoning atau penalaran moral ialah salah satu kebutuhan pokok seluruh insan dalam kehidupan. Moral reasoning atau penalaran moral merupakan upaya dalam memecahkan masalah moral dengan menggunakan logika yang sehat. Dalam berlogika secara sehat seseorang harus mampu memahami dengan baik masalah yang sedang dihadapi sebelum memutuskan pemecahan masalah seperti apa yang akan diambilnya. Begitu juga dengan mahasiswa akuntansi ketika mereka dihadapkan pada berbagai kasus pelanggaran etika yang dilakukan para akuntan, mereka akan memiliki Persepsi Etis atas kejadian tersebut.

Hasil penelitian Al-Fithrie (2015) menemukan bahwa moral reasoning memiliki dampak positif dan signifikan terhadap persepsi etis mahasiswa akuntansi. Hal ini berarti bahwa mahasiswa akuntansi dengan tingkat moral reasoning tinggi dalam memberikan persepsi etis dari kasus pelanggaran etika akan mendasarkan perilaku akuntan tersebut pada prinsip-prinsip moral. Sebaliknya, mahasiswa akuntansi dengan tingkat moral reasoning rendah cenderung mengabaikan prinsip-prinsip moral dalam memberikan persepsi etis atas kasus pelanggaran etika. Afdal (2008) juga melakukan penelitian mengenai pengaruh penalaran moral dan sikap lingkungan terhadap akuntabilitas lingkungan. Hasil penelitiannya adalah peranan moral dan sikap lingkungan sebagai determinasi dukungan akuntabilitas lingkungan, dari hasil regresi yang melibatkan faktor demografis, gender dan asal universias, menunjukkan bahwa dukungan terhadap akuntabilitas lingkungan dipengaruhi oleh institusi pendidikan yang di tempati oleh mahasiswa akuntansi menuntut ilmu. Hasil penelitian Sugiharti (2016) mengenai pengaruh moral reasoning dan ethical sensitivity terhadap persepsi etis mahasiswa akuntansi dengan gender sebagai variabel moderasi berhasil membuktikan dugaan peneliti bahwa semakin tinggi tingkat moral reasoning yang dimiliki mahasiswa akuntansi, maka persepsi etis mahasiswa akuntansi akan semakin baik. Berdasarkan uraian penjelasan di atas maka rumusan hipotesis sebagai berikut. 
$\mathrm{H}_{3}$ : Moral Reasoning berpengaruh positif pada persepsi etis mahasiswa akuntansi

Teori motivasi dapat disimpulkan sebagai alasan yang mendorong seseorang untuk menyelesaikan pekerjaan atau tanggung jawabnya adalah karena adanya kewajiban untuk memenuhi kebutuhan hidup, baik secara material maupun non material. Klasifikasi kebutuhan tersebut mulai dari pemenuhan kebutuhan yang paling dasar sampai ke tingkatan kebutuhan yang lebih tinggi. Terdapat berbagai alasan bagi mahasiswa untuk memenuhi segala kebutuhan dan alasan itu mendorong mahasiswa untuk memenuhi kebutuhannya. Apabila dorongan dirasa kuat, maka motivasi yang dimiliki akan tinggi dan usaha untuk memahami akuntansi yang ditimbulkan akan tinggi, begitu pula sebaliknya. Jadi berdasarkan uraian diatas, motivasi seorang mahasiswa merupakan dorongan dalam diri seorang mahasiswa untuk menjalankan tingkat usaha yang lebih tinggi untuk dapat memenuhi kebutuhannya setelah menyelesaikan gelar sarjana di perguruan tinggi dengan berpedoman pada prilaku etis.

Persepsi adalah bagaimana orang-orang melihat atau menginterpretasikan peristiwa, objek, serta manusia. Orang-orang bertindak atas dasar persepsi mereka dengan mengabaikan apakah persepsi itu mencerminkan kenyataan sebenarnya. Menurut Lubis (2011) definisi persepsi yang formal adalah proses dimana seseorang memilih, berusaha, dan menginterprestasikan rangsangan ke dalam suatu gambaran yang terpadu dan penuh arti.

Persepsi diartikan sebagai penerimaan atau pandangan seseorang melalui suatu proses yang didapat dari pengalaman dan pembelajaran sehingga seseorang mampu untuk memutuskan mengenai suatu hal. Persepsi adalah pengalaman tentang objek, peristiwa, atau hubungan-hubungan yang diperoleh dengan menyimpulkan informasi dan menafsirkan pesan (Jalaludin, 1999).

Persepsi seseorang dapat dipengaruhi oleh dua faktor, yakni fungsional dan struktural. Faktor fungsional bersumber dari pengalaman masa lalu dan hal lainnya yang lebih bersifat personal, sedangkan struktural berasal dari stimulasi fisik serta efek saraf pada sistem saraf seseorang. Menurut Rowe and Boulgarides (1992) persepsi dapat dikatakan merupakan unsur yang penting sebagai gerbang awal masuknya informasi dari lingkungan atau situasi dari luar. Persepsi akan mempengaruhi tanggapan seseorang akan suatu informasi baru atau yang bersifat dari luar, seseorang juga akan menggunakan panca inderanya untuk merespon informasi yang masuk.

Love of money atau kecintaan seseorang pada uang merupakan konsep untuk menggambarkan ukuran perasaan subjektif seseorang pada uang. Love of money sangat penting digunakan sebagai pertimbangan dalam menerima karyawan, karena kecintaan pada uang mampu mempengaruhi perilaku etisnya. Karyawan di Hongkong dengan love of money yang tinggi cenderung merasa kurang puas pada pekerjaan mereka (Elias dan Farag, 2010). Love of money sangat berkaitan dengan konsep ketamakan yang berpengaruh pada perilaku etis seseorang. Love of money dapat mempengaruhi psikologis seseorang dimana mereka akan melakukan segala cara untuk mendapatkan uang termasuk tindakan tidak etis. Namun love of money yang tinggi dapat dimanfaatkan untuk meningkatkan motivasi untuk semangat dalam kerja, dapat dihormati dalam 
masyarakat, serta tolak ukur keberhasilan yang telah mereka raih (Pradanti and Prastiwi, 2014).

\section{METODE PENELITIAN}

Penelitian ini dilakukan di Fakultas Ekonomi dan Bisnis Universitas Udayana yang beralamat di Jl. P. B. Sudirman Denpasar. Populasi dari penelitian ini adalah mahasiswa jurusan akuntansi Fakultas Ekonomi dan Bisnis program diploma angkatan 2016 yang berjumlah 65 orang, mahasiswa S1 akuntansi angkatan 2015 yang berjumlah 154 orang, mahasiswa PPAK angkatan 2018 yang berjumlah 44 orang dan mahasiswa S2 akuntansi angkatan 2017 berjumlah 24 orang. Peneliti memilih program diploma angkatan 2016 yang berjumlah 65 orang, mahasiswa S1 akuntansi angkatan 2015 yang berjumlah 154 orang, mahasiswa PPAK angkatan 2018 yang berjumlah 44 orang dan mahasiswa S2 akuntansi angkatan 2017 berjumlah 24 orang karena mereka merupakan caloncalon freshgraduate. Freshgraduate dipilih karena dalam memasuki dunia kerja, mahasiswa yang baru lulus belum memiliki pengalaman kerja sehingga dalam penerapannya mahasiswa perlu memahami faktor-faktor yang dapat mempengaruhi persepsi etis. Sampel dalam penelitian ini adalah mahasiswa akuntansi program diploma angkatan 2016, S1 akuntansi angkatan 2015, PPAK angkatan 2018 dan mahasiswa akuntansi program S2 angkatan 2017. Metode penentuan sampel dalam penelitian ini menggunakan metode probability sampling digunakan dengan menggunakan teknik random sederhana maka dapat ditetapkan besarnya minimal sampel dari populasi yaitu 167 mahasiswa.

Analisis regresi linier berganda merupakan analisis yang digunakan untuk mengetahui hubungan dan pengaruh variabel-variabel bebas (independen) terhadap variable terikat (dependen). Maka persamaan strukturalnya sebagai berikut:

$$
Y=\alpha+\beta_{1} X_{1}+\beta_{2} X_{2}+\beta_{3} X_{3} \varepsilon_{i}
$$

Keterangan:

$\begin{array}{ll}Y & : \text { Persepsi Etis } \\ \alpha & : \text { Konstanta } \\ \beta_{1} X_{1} & \text { : Tingkat Pendidikan } \\ \beta_{2} X_{2} & \text { : Love of Money } \\ \beta_{3} X_{3} & \text { : Moral Reasoning } \\ \varepsilon & \text { :error }\end{array}$

\section{HASIL DAN PEMBAHASAN}

Statistik deskriptif digunakan untuk memberikan gambaran dari suatu data yang dilihat dari jumlah sampel, nilai minimum, nilai maksimum, nilai rata-rata (mean), dan standar deviasi dari masing-masing variabel di dalam penelitian. Berdasarkan data olahan SPSS yang meliputi variabel tingkat pendidikan, love of money, moral reasoning dan persepsi etis mahasiswa akuntansi, didapat hasil analisis data untuk statistik deskriptif yang dapat dilihat pada tabel 1. 
Tabel 1. Hasil Statistik Deskriptif

\begin{tabular}{lccccc}
\hline & N & Minimum & Maximum & Mean & $\begin{array}{c}\text { Std. } \\
\text { Deviation }\end{array}$ \\
\hline X1 (Tingkat Pendidikan) & 167 & 1,00 & 4,00 & 2,40 & 0,91 \\
X2 (Love of Money) & 167 & 1,16 & 3,42 & 2,72 & 0,42 \\
X3 (Moral Reasoning) & 167 & 1,00 & 3,57 & 2,72 & 0,50 \\
Y (Persepsi Etis) & 167 & 1,00 & 3,13 & 2,40 & 0,45 \\
\hline
\end{tabular}

Sumber: Data Penelitian, 2019

Berdasarkan tabel 1 bahwa jumlah pengamatan $(\mathrm{N})$ pada penelitian ini adalah sebanyak 167 . Variabel tingkat pendidikan (X1) memiliki nilai minimum sebesar 1,00 dan nilai maksimum sebesar 4,00 dengan nilai rata- rata sebesar 2,40. Deviasi standar pada variabel idealisme adalah sebesar 0,91.

Variabel Love of Money (X2) memiliki nilai minimum sebesar 1,16 dan nilai maksimum sebesar 3,42 dengan nilai rata-rata sebesar 2,72. Standar devisiasi pada variabel relativisme adalah sebesar 0,42 . Hasil uji normalitas Variabel Love of Money (X2) sebagai berikut.

Tabel 2. Hasil Uji Normalitas Variabel Love of Money

\begin{tabular}{|c|c|c|c|c|}
\hline \multirow{2}{*}{\multicolumn{2}{|c|}{$\begin{array}{l}\text { Love of Money } \\
(X 2)\end{array}$}} & \multicolumn{3}{|c|}{ Shapiro-Wilk } \\
\hline & & Statistic & $\mathrm{df}$ & Sig. \\
\hline \multirow[t]{25}{*}{ Y (Persepsi Etis) } & 2,23 & 0,55 & 5 & 0,00 \\
\hline & 2,26 & 0,75 & 3 & 0,00 \\
\hline & 2,29 & 0,75 & 3 & 0,00 \\
\hline & 2,32 & 0,68 & 5 & 0,00 \\
\hline & 2,35 & 0,63 & 4 & 0,00 \\
\hline & 2,39 & & & \\
\hline & 2,45 & 0,68 & 5 & 0,00 \\
\hline & 2.61 & 0,89 & 7 & 0,30 \\
\hline & 2,65 & 0,89 & 10 & 0,18 \\
\hline & 2,68 & 0,90 & 5 & 0,42 \\
\hline & 2,71 & & & \\
\hline & 2,74 & 0,80 & 6 & 0,07 \\
\hline & 2,77 & & & \\
\hline & 2,81 & 0,75 & 3 & 0,00 \\
\hline & 2,84 & 0,88 & 5 & 0,30 \\
\hline & 2,87 & 0,68 & 5 & 0,00 \\
\hline & 2,90 & 0,78 & 7 & 0,02 \\
\hline & 2,94 & 0,85 & 12 & 0,04 \\
\hline & 2,97 & 0,77 & 12 & 0,00 \\
\hline & 3,00 & 0,81 & 9 & 0,03 \\
\hline & 3,03 & 0,81 & 10 & 0,02 \\
\hline & 3,06 & 0,84 & 10 & 0,04 \\
\hline & 3,10 & 0,94 & 6 & 0,66 \\
\hline & 3,32 & & & \\
\hline & 3,39 & 0,755 & 3 & 0,00 \\
\hline
\end{tabular}

Sumber: Data Penelitian, 2019

Tabel 2 Berdasarkan hasil uji normalitas di atas dapat terlihat bahwa angka signifikansi uji Shapiro Wilk Sig. > 0.05. Kesimpulan hasil di atas adalah karena angka signifikansi lebih besar dari 0.05 menunjukkan bahwa data berdistribusi normal. 
Variabel Moral Reasoning (X3) memiliki nilai minimum sebesar 1,00 dan nilai maksimum sebesar 3,57 dengan nilai rata-rata sebesar 2,72. Standar devisiasi pada variabel etika adalah sebesar 0,50. Hasil uji normalitas Variabel Moral Reasoning (X3) sebagai berikut.

Tabel 3. Hasil Uji Normalitas Variabel Moral Reasoning

\begin{tabular}{lllll}
\hline \multicolumn{2}{c}{$\begin{array}{c}\text { Moral Reasoning } \\
(\mathrm{X} 3)\end{array}$} & \multicolumn{3}{c}{ Shapiro-Wilk } \\
\hline Y (Persepsi Etis) & 2,00 & 0,84 & 6 & Sig. \\
& 2,14 & 0,89 & 13 & 0,13 \\
& 2,42 & 0,60 & 18 & 0,00 \\
& 2,57 & 0,70 & 9 & 0,00 \\
& 2,71 & 0,84 & 20 & 0,00 \\
& 2,85 & 0,86 & 26 & 0,00 \\
& 3,00 & 0,82 & 45 & 0,00 \\
& 3,42 & 0,69 & 13 & 0,00 \\
& 3,57 & 0,75 & 3 & 0,00 \\
\hline
\end{tabular}

Sumber: Data Penelitian, 2019

Variabel persepsi etis mahasiswa akuntansi $(\mathrm{Y})$ memiliki nilai minimum sebesar 1,00 dan nilai maksimum sebesar 3,13 dengan nilai rata-rata sebesar 2,40. Standar devisiasi pada variabel persepsi mahasiswa akuntansi atas perilaku etis akuntan adalah sebesar 0,45.

Untuk melihat apakah data yang digunkan dalam penelitian telah terdistribusi normal dapat dilihat dengan uji saphiro wilk. Uji normalitas dengan menggunakan uji saphiro wilk bertujuan meyakinkan apakah residual dapat terdistribusi dengan normal. Hasil uji normalitas variabel tingkat pendidikan ditunjukkan pada tabel 4 .

Tabel 4. Hasil Uji Normalitas Variabel Tingkat Pendidikan

\begin{tabular}{cccccc}
\hline & \multicolumn{4}{c}{ Tingkat Pendidikan } & \multicolumn{3}{c}{ Shapiro - Wilk } \\
$(\mathrm{X} 1)$ & & Statistic & df & Sig \\
\hline $\mathrm{Y}$ & 1,00 & 0,93 & & 25 & 0,10 \\
& 2,00 & 0,93 & & 74 & 0,00 \\
& 3,00 & 0,90 & & 44 & 0,00 \\
4,00 & 0,91 & & 24 & 0,05 \\
\hline
\end{tabular}

Sumber: Data Penelitian, 2019

Dalam penelitian ini untuk mendeteksi gejala multikolinieritas dilakukan dengan melihat nilai Variance Inflation Factor (VIF). Multikolinearitas dapat dilihat dari nilai tolerance dan VIF (Varian Inflaction Factor), yaitu jika nilai tolerance lebih dari 10 persen dan nilai VIF kurang dari 10, berarti tidak ada multikolinearitas variabel bebas dalam model regresi ini. Hasil uji multikolinearitas ditunjukkan pada Tabel 5. 
Tabel 5. Hasil Uji Multikolinieritas

\begin{tabular}{|c|c|c|c|c|c|c|c|}
\hline \multirow[t]{2}{*}{ Model } & \multicolumn{2}{|c|}{$\begin{array}{c}\text { Unstandardized } \\
\text { Coefficient }\end{array}$} & \multirow{2}{*}{$\begin{array}{c}\begin{array}{c}\text { Standardized } \\
\text { Coefficient }\end{array} \\
\text { Beta }\end{array}$} & \multirow[b]{2}{*}{$T$} & \multirow[b]{2}{*}{ Sig. } & \multicolumn{2}{|c|}{ Collinearity Statistics } \\
\hline & $B$ & $\begin{array}{l}\text { Std. } \\
\text { Error }\end{array}$ & & & & Tolerance & VIF \\
\hline $\begin{array}{l}1 \\
\text { (Constant) }\end{array}$ & 2,30 & .242 & & 9,50 & 0,00 & & \\
\hline $\begin{array}{l}\text { Tingkat } \\
\text { Pendidikan } \\
\text { (X1) }\end{array}$ & $-0,11$ & 0,03 & $-0,22$ & $\begin{array}{c}- \\
3,10\end{array}$ & 0,00 & 0,96 & 1,03 \\
\hline $\begin{array}{l}\text { Love of } \\
\text { Money (X2) }\end{array}$ & $-0,49$ & 0,19 & $-0,46$ & $\begin{array}{c}- \\
2,55\end{array}$ & 0,01 & 0,15 & 6,52 \\
\hline $\begin{array}{l}\text { Moral } \\
\text { Reasoning } \\
\text { (X3) }\end{array}$ & 0,63 & 0,16 & 0,69 & 3,79 & 0,00 & 0,15 & 6,58 \\
\hline
\end{tabular}

Sumber: Data Penelitian, 2019

Berdasarkan Tabel 5 dapat dilihat bahwa nilai tolerance variabel bebas tidak ada yang kurang dari 10 persen $(0,1)$ dan seluruh variabel bebas memiliki nilai VIF kurang dari 10. Sehingga dapat disimpulkan bahwa pada data penelitian ini, tidak terjadi multikolinearitas antara variabel bebas dalam model regresi ini.

Dalam penelitian ini, untuk mendeteksi ada atau tidaknya heteroskedastisitas dapat dilakukan dengan melakukan Uji Glejser, yaitu dengan meregres variabel bebas terhadap absolute residual. Jika variabel terikat signifikan mempengaruhi variabel bebas, maka ada indikasi terjadi heterokedastisitas. Hasil uji heteroskedastisitas dapat dilihat pada Tabel 6.

Tabel 6. Hasil Uji Heteroskedastisitas

\begin{tabular}{|c|c|c|c|c|c|c|}
\hline \multirow{2}{*}{\multicolumn{2}{|c|}{ Model }} & \multicolumn{2}{|c|}{$\begin{array}{l}\text { Unstandardized } \\
\text { Coefficients }\end{array}$} & \multirow{2}{*}{$\begin{array}{c}\text { Standardized } \\
\text { Coefficients } \\
\text { Beta } \\
\end{array}$} & \multirow[t]{2}{*}{$\mathrm{t}$} & \multirow[t]{2}{*}{ Sig. } \\
\hline & & B & Std. Error & & & \\
\hline \multirow{4}{*}{1} & (Constant) & 0,64 & 0,13 & & 5.02 & 0,000 \\
\hline & $\begin{array}{l}\text { X1 (Tingkat } \\
\text { Pendidikan) }\end{array}$ & 0,03 & 0,02 & 0,11 & 1.53 & 0,12 \\
\hline & X2 (Love of Money) & 0,05 & 0,10 & 0,09 & 0,50 & 0,61 \\
\hline & X3 (Moral Reasoning) & $-0,19$ & 0,09 & $-0, .40$ & -2.14 & 0,03 \\
\hline
\end{tabular}

Sumber: Data Penelitian, 2019

Berdasarkan olahan data dengan SPSS pada Tabel 6 terlihat bahwa tidak ada pengaruh variabel bebas $\left(X_{1}, X_{2}\right.$ dan $\left.X_{3}\right)$ terhadap absolute residual (abs_res), baik secara serempak maupun parsial karena nilai Sig. lebih besar dari 0,05. Dengan demikian model yang dibuat tidak mengandung gejala heteroskedastisitas, sehingga layak digunakan untuk memprediksi.

Penelitian ini menganalisis data menggunakan metode analisis regresi berganda. Analisis regresi berganda digunakan untuk mengetahui dan menunjukkan arah serta besarnya pengaruh tingkat pendidikan, love of money, moral reasoning pada persepsi etis mahasiswa akuntansi.

Model analisis ini yang digunakan sebagai variabel bebas adalah tingkat pendidikan $\left(\mathrm{X}_{1}\right)$, love of money $\left(\mathrm{X}_{2}\right)$, moral reasoning $\left(\mathrm{X}_{3}\right)$. Sedangkan variabel 
terikat pada penelitian ini adalah persepsi etis mahasiswa akuntansi (Y). Analisis ini menggunakan bantuan Statistical Package For Social Science (SPSS) 21.0 dalam pengolahan.

Tabel 7. Hasil Analisis Regresi Berganda

\begin{tabular}{|c|c|c|c|c|c|}
\hline \multirow{2}{*}{\multicolumn{2}{|c|}{ Model }} & \multicolumn{2}{|c|}{ Unstandardized Coefficient } & \multirow{2}{*}{$\begin{array}{c}\text { Standardized } \\
\text { Coefficient }\end{array}$} & \multirow[b]{2}{*}{ Sig. } \\
\hline & & B & Std. Error & & \\
\hline & (Constant) & 2.30 & 0.24 & & 0.00 \\
\hline & X1 (Tingkat Pendidikan) & 0.11 & 0.03 & 0.22 & 0.00 \\
\hline & X2 (Love of Money) & -0.49 & 0.19 & -0.46 & 0.01 \\
\hline & X3 (Moral Reasoning) & 0.63 & 0.16 & 0.69 & 0.00 \\
\hline & nifikansi F $\quad: 0.00$ & & & & \\
\hline & quare & & & & \\
\hline
\end{tabular}

Sumber: Data Penelitian, 2019

Berdasarkan hasil analisis yang disajikan pada Tabel 7 maka dapat disusun persamaan regresi sebagai berikut:

Keterangan:

$$
Y=2,30+0,11 X_{1}-0,49 X_{2}+0,63 X_{3}
$$

Y : Persepsi Etis Mahasiswa Akuntansi

$\mathrm{X}_{1} \quad$ : Tingkat Pendidikan

$\mathrm{X}_{2}$ : Love of Money

$\mathrm{X}_{3} \quad$ : Moral Reasoning

Hasil analisis kelayakan model $F$ dapat dilihat pada Tabel 7 menunjukkan bahwa nilai $\mathrm{F}$ hitung sebesar 11,64 dengan nilai signifikansi uji $\mathrm{F}$ yaitu sebesar 0,000 lebih kecil dari 0,05 yang berarti $\mathrm{H}_{1}$ diterima dan $\mathrm{H}_{0}$ ditolak. Hasil ini memberikan makna bahwa variabel tingkat pendidikan, love of money, moral reasoning dapat atau layak digunakan untuk memprediksi variabel persepsi etis mahasiswa akuntansi di Fakultas Ekonomi dan Bisnis Universitas Udayana.

Koefisien determinasi $\left(R^{2}\right)$ bertujuan untuk mengukur seberapa jauh kemampuan model dalam menerangkan variasi variabel dependen. Besarnya nilai Adjusted $R^{2}$ adalah sebesar 0,11. Hal ini berarti bahwa 11 persen variasi besarnya persepsi etis mahasiswa akuntansi dapat dijelaskan oleh tingkat pendidikan, love of money, moral reasoning. Sedangkan sisanya sebesar 89 persen dipengaruhi oleh variabel-variabel lain diluar model penelitian.

Nilai $\mathrm{t}$ hitung pada variabel tingkat pendidikan adalah sebesar $-2,55$ dengan tingkat signifikansi 0,01. Dengan menggunakan batas signifikansi 0,05 maka signifikansi tersebut dibawah taraf 5 persen yang berarti $\mathrm{H}_{0}$ ditolak dan $\mathrm{H}_{1}$ diterima. Hal ini menunjukkan bahwa tingkat pendidikan berpengaruh positif pada persepsi etis mahasiswa akuntansi.

Nilai $t$ hitung pada variabel love of money adalah sebesar -3,10 dengan tingkat signifikansi 0,01. Dengan menggunakan batas signifikansi 0,05 maka signifikansi tersebut dibawah taraf 5 persen yang berarti $\mathrm{H}_{0}$ ditolak dan $\mathrm{H}_{2}$ diterima. Hal ini menunjukkan bahwa love of money berpengaruh negatif pada tingkat persepsi etis mahasiswa akuntansi.

Nilai t hitung pada variabel moral reasoning adalah sebesar $-3,79$ dengan tingkat signifikansi 0,00. Dengan menggunakan batas signifikansi 0,05 maka 
signifikansi tersebut dibawah taraf 5 persen yang berarti $\mathrm{H}_{0}$ ditolak dan $\mathrm{H}_{3}$ diterima. Hal ini menunjukkan bahwa moral reasoning berpengaruh negatif pada tingkat persepsi etis mahasiswa akuntansi.

Berdasarkan hasil perhitungan Analisis Regresi Berganda pada Tabel 7 diperoleh nilai signifikansi uji t untuk variabel tingkat pendidikan $\left(\mathrm{X}_{1}\right)$ pada persepsi etis mahasiswa akuntansi sebesar 0,01 dimana lebih kecil dari nilai taraf nyata yaitu 0,05 . Hal ini menunjukkan bahwa tingkat pendidikan berpengaruh positif pada persepsi etis mahasiswa akuntansi. Semakin tinggi tingkat pendidikan, maka akan semakin tinggi persepsi etis yang dimiliki mahasiswa akuntansi. Semakin rendah tingkat pendidikan akan semakin rendah persepsi etis yang dimilikinya. semakin tinggi tingkat pendidikan, pengetahuan yang dimiliki juga akan meningkat. Semakin banyak pengetahuan yang mereka ketahui maka akan membantu mereka untuk bisa memberikan persepsi maupun tanggapan terhadap krisis etis yang melibatkan profesi akuntan.

Penelitian ini sejalan dengan hasil penelitian Dellaportas (2006), (Elias, 2010) dan Lopez et al. (2005) yang menunjukkan bahwa tingkat pendidikan berpengaruh positif terhadap perilaku etis, khususnya pada mahasiswa akuntansi. Semakin tinggi tingkat pendidikan maka semakin banyak pengetahuan yang dimiliki dengan demikian akan membantu mahasiswa untuk bisa memberikan persepsi maupun tanggapan terhadap krisis etis yang melibatkan profesi akuntan.

Berdasarkan hasil perhitungan Analisis Regresi Berganda pada Tabel 7 diperoleh nilai signifikansi uji $t$ untuk variabel love of money $\left(\mathrm{X}_{2}\right)$ pada persepsi etis mahasiswa akuntansi sebesar 0,01 dimana lebih kecil dari nilai taraf nyata yaitu 0,05 . Hal ini menunjukkan bahwa love of money berpengaruh negatif pada persepsi etis mahasiswa akuntansi. Semakin tinggi tingkat love of money yang dimiliki, maka akan semakin rendah persepsi etis mahasiswa akuntansi. Semakin rendah tingkat love of money yang dimiliki, akan semakin tinggi persepsi etis yang dimiliki.

Teori motivasi menjelaskan bahwa manusia memiliki 5 kebutuhan dasar yang harus dipenuhi. Dalam pemenuhannya sebagian besar melibatkan kebutuhan akan uang yang berdampak pada kecintaan berlebih pada uang. Seseorang dengan kecintaan terhadap uang akan bersikap tamak dan mengutamakan uang diatas segalanya, termasuk melakukan perilaku tidak etis. Seseorang akan melakukan apapun demi uang.

Penelitian ini sejalan dengan hasil penelitian Charismawati (2011), Aziz (2015), Tang dan Chiu (2003) yang setuju bahwa seseorang dengan tingkat love of money yang tinggi cenderung berperilaku tidak etis. Kecintaan yang tinggi terhadap uang membuat seseorang akan melakukan apapun guna mendapatkan uang yang banyak, termasuk perilaku yang tidak etis.

Berdasarkan hasil perhitungan Analisis Regresi Berganda pada Tabel 7 diperoleh nilai signifikansi uji t untuk variabel moral reasoning $\left(\mathrm{X}_{3}\right)$ pada persepsi etis mahasiswa akuntansi sebesar 0,00 dimana lebih kecil dari nilai taraf nyata yaitu 0,05 . Hal ini menunjukkan bahwa moral reasoning berpengaruh positif pada persepsi etis mahasiswa akuntansi. Semakin tinggi tingkat moral reasoning yang dimiliki, maka akan semakin tinggi persepsi etis mahasiswa akuntansi. Semakin 
rendah tingkat moral reasoning yang dimiliki, akan semakin rendah persepsi etis yang dimiliki.

Teori motivasi merupakan teori yang didasarkan pada kebutuhan insan dan kepuasannya. Moral reasoning atau penalaran moral ialah salah satu kebutuhan pokok seluruh insan dalam kehidupan. Moral reasoning atau penalaran moral merupakan upaya dalam memecahkan masalah moral dengan menggunakan logika yang sehat. Dalam berlogika secara sehat seseorang harus mampu memahami dengan baik masalah yang sedang dihadapi sebelum memutuskan pemecahan masalah seperti apa yang akan diambilnya.

Penelitian ini sejalan dengan hasil penelitian Al-Fithrie (2015), Afdal (2012), dan Sugiharti (2013) yang setuju bahwa seseorang dengan tingkat moral reasoning yang tinggi akan memberikan persepsi etis dari khasus pelanggaran etika berdasarkan prinsip-prinsip moral. moral reasoning yang tinggi akan membuat persepsi etis mahasiswa semakin baik.

Penelitian yang dilakukan diharapkan dapat memberikan kontribusi mengenai pengaruh tingkat pendidikan, love of money, dan moral reasoning pada persepsi etis mahasiswa akuntansi. Hasil uji dalam penelitian ini ditemukan bahwa tingkat pendidikan dan moral reasoning akan berbanding lurus dengan persepsi etis yang dimiliki mahasiswa, love of money akan memiliki nilai yang berbanding terbalik dengan persepsi etis yang dimiliki mahasiswa.

Teori motivasi menjelaskan seseorang memiliki kebutuhan pokok yang harus dipenuhi sehingga akan mempengaruhi perilaku etisnya. Seseorang dengan tingkat pendidikan dan moral reasoning yang tinggi akan berperilaku etis sesuai dengan prinsip-prinsip moral yang berlaku. Seseorang dengan love of money yang tinggi akan memiliki sifat tamak dan berperilaku tidak etis.

Penelitian ini memberikan implikasi pada pihak kampus guna memperbaiki sistem pendidikan yang ada sehingga mampu menghasilkan lulusan yang berkompeten dan siap bekerja, serta meminimalisir berbagai kasus kecurangan yang melibatkan profesi akuntan.

\section{SIMPULAN}

Mahasiswa akuntansi dengan tingkat pendidikan yang tinggi akan memiliki persepsi etis yang tinggi pula. Tingkat pendidikan yang tinggi, akan meningkatkan persepsi etis yang dimiliki mahasiswa akuntansi.

Mahasiswa akuntansi dengan tingkat love of money yang tinggi akan memiliki persepsi etis yang rendah. Kecintaan pada uang yang tinggi mengakibatkan seseorang akan melakukan segalanya demi mendapatkan uang dan cenderung mengarah pada perilaku tidak etis.

Mahasiswa akuntansi dengan tingkat moral reasoning yang tinggi akan memberikan persepsi etis dari khasus pelanggaran etika berdasarkan prinsipprinsip moral. Moral reasoning yang tinggi akan membuat persepsi etis mahasiswa semakin baik.

Berdasarkan data kuesioner variabel love of money skor tertinggi pada pernyataan no. 20 mengenai uang harus digunakan untuk mengontrol perilaku yang berhubungan dengan pekerjaan, artinya sebagian besar mahasiswa akuntansi masih belum dapat mengartikan bahwa untuk mengontrol perilaku 
tidak hanya dengan uang, sehingga saran yang dapat diberikan yaitu sebaiknya mahasiswa dalam mengontrol perilaku yang berhubungan dengan pekerjaan tidak harus dengan uang, dapat juga dengan hal lain seperti menciptakan prestasi yang akan dihargai leh orang lain.

Berdasarkan data kuesioner variabel etika skor tertinggi terletak pada pernyataan no. 8 yaitu mengenai pembayaran gelap untuk mengembangkan bisnis di luar negeri, sehingga saran yang dapat diberikan yaitu mahasiswa harus lebih meningkatkan persepsi etisnya agar tidak salah dalam bertindak dan meningkatkan regulasi bisnisnya.

\section{REFERENSI}

Afdal, A. (2008) 'Pengaruh Penalaran Moral dan Sikap Lingkungan terhadap Akuntabilitas Lingkungan', SNA Proceeding. doi: 10.1016/j.eatbeh.2007.10.002.

Al-Fithrie, N. L. (2015) 'Pengaruh Moral Reasoning dan Ethical Sensitivity Terhadap Persepsi Etis Mahasiswa Akuntansi dengan Gender Sebagai Variabel Moderasi', Skripsi. doi: 10.1007/s13398-014-0173-7.2.

Aziz, T. ilnu (2015) 'Pengaruh Love of Money dan Machivellian Terhadap Persepsi Etis Mahasiswa Akuntansi', Jurnal Nominal, IV(I), pp. 4140-4143. doi: 10.1016/j.jdermsci.2014.05.009.

Chairunnisa, N. (2018). Eks Dirut Pertamina Karen Agustiawan Jadi Tersangka Kasus Korupsi. Retrieved July 28, 2018, from https://www.nasional.tempo.co/amp/1076276/eks-dirut-pertaminakaren-agustiawan-jadi-tersangka-kasus-korupsi

Charismawati, C. D. (2011) 'Analisis Hubungan Antara Love of Money dengan Persepsi Etika Mahasiswa Akuntansi', Jurnal Ilmiah Akuntansi dan Bisnis. Available http:/ / eprints.undip.ac.id/29310/1/Jurnal_Celvia_Dhian_C.pdf.

Dellaportas, S. (2006) 'Making a Difference with a Discrete Course on Accounting Ethics', Journal of Business Ethics, 65(4), pp. 391-404. doi: 10.1007/s10551-0060020-7.

Elias, R. Z. and Farag, M. (2010) 'The Relationship Between Accounting Students Love of Money and Their Ethical Perception', Managerial Auditing Journal, 25(3), pp. 269-281. doi: 10.1108/02686901011026369.

Frederickson, N., Miller, a and Cline, T. (2008) 'Educational Psychology', Educational Psychology, 77, pp. 41-64. doi: 10.1017/CBO9781107415324.004.

Hasibuan, M. S. P. (2011) 'Manajemen Sumber Daya Manusia', Edisi Revisi Jakarta: Bumi Aksara. doi: 10.1017/CBO9781107415324.004.

Hidayat, F. (2018). Tiga Pengusaha Terlibat Penggelapkan Pajak Rp7,9 Milliar. Retrieved June 30, 2018, from https:/ / www.wartaekonomi.co.id/berita154310/tiga-pengusaha-terlibatpenggelapan-pajak-rp79-milliar.html

Jalaludin, R. (1999) Psikologi Komunikasi; Critical Communication. Bandung: Remaja Rosdakarya.

Kohlberg, L. (1975) 'The Approach Cognitive-Developmental to Moral', Phi Delta Kappa International, 56(10), pp. 670-677.

Kohlberg, L. (1981) The Philosophy of Moral Development, Essays on Moral 
Development. doi: 10.1109/ICRA.2011.5980329.

Lubis, I. A. (2011) Akuntansi Keperilakuan. 2nd edn. Jakarta: Salemba Empat.

Maslow, A. H. (1955) 'Motivation and Personality', Journal of Business Ethics, pp. 62-27. doi: $10.1037 /$ h0039764.

Pradanti, N. R. and Prastiwi, A. (2014) Analisis Pengaruh Love of Money Terhadap Persepsi Etis Mahasiswa Akuntansi, Journal of Accounting. Available at: http:/ / ejournal-s1.undip.ac.id/index.php/dbr.

Rest, J. R. et al. (2000) 'A Neo-Kohlbergian Approach to Materity Research', Journal of Moral Education, 29(4), pp. 381-395. doi: 10.1080/03057240020015001.

Richmond, K. A. (2001) 'Ethical Reasoning, Machiavellian Behavior, and Gender: The impact on Accounting Students Ethical Decision Making', Dissertations and Theses, p. 85-85 p. doi: 10.1017/CBO9781107415324.004.

Robbins, S. P. and Judge, T. A. (2015) Perilaku Organisasi (Organizational Behavior). 16th edn. Jakarta: Salemba Empat.

Sipayung, E. and Cahyonowati, N. (2015) 'Analisis Pengaruh Aspek Demografi, Status Sosial Ekonomi Dan Pengalaman Kerja Terhadap Persepsi Etis Mahasiswa Akuntansi Dengan Love of Money Sebagai Variabel Intervening', 4, pp. 1-15. Available at: http://eprints.undip.ac.id/45685/.

Sugiharti, A. (2016) 'Pengaruh Moral Reasoning dan Ethical Sensitivity Terhadap Persepsi Etis Mahasiswa Akuntansi dengan Gender sebagai Variabel Moderasi', Journal of Business Ethics.

Tang, T. L. P. and Chiu, R. K. (2003) 'Income, Money Ethic, Pay Satisfaction, Commitment, and Unethical Behavior: Is the Love of Money the Root of Evil for Hong Kong Employees?', Journal of Business Ethics, 46(1), pp. 13-30. doi: 10.1023/A:1024731611490.

Welton, R. E. and Lagrone, R. M. (1994) 'Promoting the Moral Development of Accounting Graduate Students: an Instructional Design and Assessment', Accounting Education, 3(1), pp. 35-50. doi: 10.1080/09639289400000004. 